\title{
The Effectiveness of Using Problem Based Learning and Video Scribe
}

\author{
R. A. Rica Wijayanti ${ }^{1,{ }^{*}}$ Didik Hermanto ${ }^{1,}$ Mety Liesdiani ${ }^{1}$ \\ ${ }^{1}$ Departement of Mathematics Education STKIP PGRI Bangkalan, Indonesia \\ *Corresponding author. Email: ricawijayanti@stkippgri-bkl.ac.id
}

\begin{abstract}
This study aims to describe the effectiveness of the Model Problem-Based Learning and video scribe media in terms of mathematical reasoning and motivation to learn. This study was quasi-experimental with the nonequivalent control group design. The population of this research was all students in SDN Bilaporah 5, Bangkalan and the research sample was VI-A and VI-B were randomly selected. The instrument used in this study is the mathematical reasoning test and motivation in learning questionnaire. The data were analyzed by using a multivariate test Hotelling's T, MANOVA, and t-test. The analysis regarding at the significance level of $5 \%$. The results of this study showed that (1) the teaching of mathematics by using the model problem-based learning and video scribe media is effective in terms of mathematical reasoning and motivation to learn; (2)the model problem-based learning and video scribe media are better than the conventional teaching model.
\end{abstract}

Keywords: effectiveness model problem-based learning, video scribe media, mathematical reasoning, motivation to learn

\section{INTRODUCTION}

The existence of a paradigm shift in the current learning process, makes teachers have to be more creative in carrying out the teaching and learning process. This is because the teacher is not only tasked with transferring knowledge, but the teacher must also make students trained to do reasoning in solving problems related to the topic of the subject matter. However, the fact is that in the field it is very difficult for teachers to do because training students' thinking reasoning must require a specially designed learning design. Based on the researcher's experience when he became a field supervisor in a teaching campus program whose placement was at SDN Bilaporah 5 Bangkalan, students have poor thinking skills, especially in mathematics. The low reasoning of students in mathematics lessons at the school makes students have low motivation in participating in the learning process. Mathematics, which is basically always feared by many students because of the difficulty in carrying out the calculation process, will continue to be a big obstacle if the teacher is not able to design mathematics learning properly.

According to Piaget's cognitive development, there are 4 stages of child development, namely (1) the sensorimotor stage, (2) the operational stage, (3) the concrete operational stage, and (4) the operational stage. Elementary school students who are in the operational stage, where at this stage the child has the characteristic ability to use logic in solving problems, drawing conclusions, and making future plans. Therefore, children who are already in the operational stage should continue to be trained to get used to doing reasoning in solving problems. Teachers in schools have a strong role in this training process, so teachers who teach high-grade students at the elementary school level should design learning by exposing students to problem-solving

The Problem Based Learning model is one of the innovative learning models that confront students in problem-solving. This model aims to train students to get used to the process of reasoning, thinking, and being sensitive in finding the most appropriate solution for solving the problem. He said, "PBL as a course model that focuses on real-world problems [1]". This statement shows that the use of the PBL learning model used by teachers can invite students to understand some real-world problems and relate them to the theories they have learned in learning. In addition, the use of PBL can also help students 
develop thinking skills, problem-solving skills, and provide facilities for students to become active, independent, and tough individuals in dealing with problems related to the real world [2]. According to the results of research conducted by Uliyandari [3], the Problem Based Learning model can help to improve conceptual understanding and critical thinking ability of science education undergraduate students. On the other hand, the other researchers show PBL learning model can also increase student motivation to learn by solving the problem [4].

In addition to using the Problem Based Learning model, the use of learning media in a mathematics learning design is very important. Therefore, in the learning process teachers need to plan the selection of learning media as well as possible. so that the topic of learning that is abstract turns into concrete [5]. The benefit of using learning media is that it can clarify the meaning of the material being taught, not only verbally, learning is more varied, students are more active, interested and overcome space limitations [6]. Based on the results of research conducted by [7] that the application of technology-based learning media in the mathematics learning process can facilitate students in understanding mathematical concepts.

Video is one of the technology-based learning media which is included in the type of multimedia so that it is the most dynamic and effective in conveying learning messages to students, especially in today's modern era. used by an educator which contains teaching materials in the form of concepts, principles, procedures, and theories of knowledge and is presented in audio and visual form. The results of the study [8] show that the use of video tutorial media is effectively used in the learning process so that learning motivation and student learning outcomes have increased. In addition, according to [9] instructional media in the form of video has several functions, namely video media has the property of attracting attention so that it can motivate students to learn, (2) the material presented in the video can be used to develop listening skills and evaluate what has been witnessed/heard. by students, (3) the material delivered by the teacher can be more in less time. There are many ways to make interesting learning videos, but in this study, the researchers chose to make learning videos using the video scribe application. Based on the explanation above, the researcher is interested in conducting a study on the effectiveness of using the Problem Based Learning model and video scribe media in terms of mathematical reasoning and student learning motivation.

\section{METHOD}

\subsection{Research Method}

This type of research was a quasi-experiment with a non-equivalent control group design. The independent variables were model problem-based learning dan video scribe media and conventional learning. The dependent variables were mathematical reasoning and motivation to learn. This study used two classes, namely the experimental class and the control class. In the experimental class, a problembased learning model will be applied with the help of video scribe media, while in the control class a conventional learning model will be used without using learning media. The researcher chooses both classes randomly and only pays attention to the level of equality of the classes used

\subsection{Population and Sample}

The population of this research was all in SDN Bilaporah 5 Bangkalan. The population in the school is 10 classes consisting of 4 low classes and 6 high classes. Researchers chose 2 high grades randomly with the same grade level to be used as research samples. The samples of this study were students of class A and students of class B. Students in class A were used as the experimental class while students in class B were used as the control class.

\subsection{Research Procedures}

This research used a quasi-experiment with the nonequivalent control group design. Both classes, experimental class (treated by model problem-based learning with vie scribe media) and control class (not treated or conventional learning model) had the pretest and post-test, and questionnaire. It had a purpose to describe the effectiveness of the model problem-based learning and video scribe media terms of mathematical reasoning and motivation to learn before and after the treatment

\subsection{Data, Instrument, and Data Collection}


Table 1. Description of students' level of mathematical reasoning

\begin{tabular}{|l|l|l|l|l|l|}
\hline & N & Min & $\max$ & $\bar{x}$ & SD \\
\hline pretest_experiment & 20 & 50 & 80 & 64.8 & 6.21 \\
\hline Posttest_experiment & 20 & 70 & 100 & 80.3 & 8.60 \\
\hline Pretest_Control & 20 & 50 & 80 & 64.9 & 6.23 \\
\hline Posttest_Control & 20 & 50 & 85 & 73.0 & 8.50 \\
\hline
\end{tabular}

Table 2. One Sample Kolmogrov Sminov Test

\begin{tabular}{|l|l|l|}
\hline \multicolumn{2}{|l|}{} & $\begin{array}{l}\text { Unstandardized } \\
\text { Residual }\end{array}$ \\
\hline \multirow{2}{|l|}{$N$} & 40 \\
\hline \multirow{2}{*}{ Normal Parameters ${ }^{\mathrm{a}, \mathrm{b}}$} & Mean & .0000000 \\
\cline { 2 - 3 } & Std. & 8.59963945 \\
& Deviation & \\
\hline \multirow{2}{*}{ Most Extreme Differences } & Absolute & .097 \\
\cline { 2 - 3 } & Positive & .054 \\
\cline { 2 - 3 } & Negative & -.097 \\
\hline Kolmogorov-Smirnov Z & .611 \\
\hline Asymp. Sig. (2-tailed) & .849 \\
\hline
\end{tabular}

This research consisted of two types of instruments such as quantitative and qualitative. The instrument used in this study is the mathematical reasoning test and motivation in learning questionnaire Mathematical reasoning test, these were quantitative data, and the motivation in learning questionnaire was qualitative data. Before the use of the research instrument, the researcher had performed an instrument validation stage. The validation stage is conducted by giving tests to the student of the other school. Then, it continued to perform the calculation by validity test item with the SPSS version 21.0 with the formula of Pearson Product Moment Correlation, if the all of instruments obtain valid so the instruments were ready to use. This data was analyzed MANOVA

\subsection{Data Analysis Technique}

The data of this research were analyzed by using a multivariate test Hotelling's T, MANOVA, and ttest. The analysis regarding at the significance level of 5\%.The Software used in this research was SPSS version 21.0 and Microsoft Excel were used in the entire test

\section{RESULT AND DISCUSSION}

\subsection{Mathematical Reasoning}

The level of students' mathematical reasoning in this research was obtained from the results of the pretest and posttest. The pretest and posttest questions were given to both groups, both the experimental group and the control group. Table 1 shows the students' mathematical reasoning data.

Based on table 1 above, it shows that the number of student samples is 20 students in the experiment class and the control class. The minimum scores for the pretest and posttest results in the experiment class 
were 50 and 70 respectively. While the minimum values for the pretest and posttest results in the control class were 50 and 80 . After the researcher gave treatment to the experiment class, the two classes were then retested and the result was the posttest score. the minimum and maximum experimental classes are 70 and 100 respectively. In the control class, the minimum and maximum values are 50 and 85 .

Table 2 above will show whether the two classes used as research samples are normally distributed or not. The results of data analysis in table 2 were obtained using the Komolgrov Smirnov Test

Based on the results of data processing in table 2 above shows that the value of Asymp. Sig (2 tailed) 0.849 is greater than 0.05 . That is, according to the basic decision-making in the Kolmogrov Smirnov test, it can be concluded that the research data is normally distributed. Therefore, the normality requirements in the regression model have been met. After carrying out the normality test process, we will carry out the process of testing the effectiveness of the use of problem-based learning models and video scribe media compared to conventional learning models. The following are the results of the effectiveness test using the manova test
After we know the effectiveness of learning models and media in terms of students' mathematical reasoning in this study, then at this point it will be shown the effectiveness of learning models and media in terms of student learning motivation. Learning motivation data will be presented in the form of a percentage. The following is a table of the results of the analysis of learning motivation from the control class and the experiment class.

In table 4 , the results of the class Sig value at the posttest are $0.01<0.05$. That is, the models and learning media used affect students' mathematical reasoning.

The results of the two tables clearly illustrate that the treatment given by the researcher in the experimental class affects students' learning motivation. Students in the experimental class revealed that the problem-based learning model and the video scribe media used were very attractive. Teachers can carry out a two-way learning process, where students are given the widest opportunity to explore their knowledge. The impact is that students are motivated to follow the learning process with happy conditions so that the teaching materials delivered can be understood more easily by students. This is different from the results of student responses

Table 3. Multivariate Test

\begin{tabular}{|c|c|c|c|c|c|c|c|c|}
\hline \multicolumn{2}{|l|}{ Effect } & Value & $\bar{F}$ & $\begin{array}{l}\text { Hypothe } \\
\text { sis df }\end{array}$ & Error df & $\overline{\text { Sig. }}$ & $\begin{array}{l}\text { Noncent. } \\
\text { Parameter }\end{array}$ & $\begin{array}{l}\text { Observed } \\
\text { Powerd }\end{array}$ \\
\hline \multirow{4}{*}{ Intercept } & Pillai's Trace & .950 & $345.232 b$ & 2.000 & 36.000 & .000 & 690.463 & 1.000 \\
\hline & Wilks' Lambda & .050 & $\begin{array}{r}345.232 \\
b\end{array}$ & 2.000 & 36.000 & .000 & 690.463 & 1.000 \\
\hline & $\begin{array}{l}\text { Hotelling's } \\
\text { Trace }\end{array}$ & 19.180 & $\begin{array}{r}345.232 \\
b\end{array}$ & 2.000 & 36.000 & .000 & 690.463 & 1.000 \\
\hline & $\begin{array}{l}\text { Roy's Largest } \\
\text { Root }\end{array}$ & 19.180 & $\begin{array}{r}345.232 \\
b\end{array}$ & 2.000 & 36.000 & .000 & 690.463 & 1.000 \\
\hline \multirow{3}{*}{ Kelas } & Pillai's Trace & .649 & 8.887 & 4.000 & 74.000 & .000 & 35.548 & .999 \\
\hline & Wilks' Lambda & .389 & $10.876 b$ & 4.000 & 72.000 & .000 & 43.502 & 1.000 \\
\hline & $\begin{array}{l}\text { Hotelling's } \\
\text { Trace }\end{array}$ & 1.477 & 12.921 & 4.000 & 70.000 & .000 & 51.685 & 1.000 \\
\hline
\end{tabular}

\subsection{Motivation to Learn}

in the control class which revealed that learning was considered less attractive so that it had an impact on 
students' learning motivation and understanding to be less than optimal.

\subsection{Discussion}

Notwithstanding the differences in the many variables involved in learning generally, the reviewed studies have clearly shown that the use of problembased learning models has proven to be more effective for educators than traditional learning models. One of the research figures who compares educators in choosing a learning model greatly affects student learning outcomes.

Table 4. Test of between-subject effect

\begin{tabular}{|c|c|c|c|c|c|c|c|c|}
\hline Source & $\begin{array}{l}\text { Dependent } \\
\text { Variable }\end{array}$ & $\begin{array}{l}\text { Type III } \\
\text { Sum of } \\
\text { Squares }\end{array}$ & df & Mean Square & $F$ & Sig. & $\begin{array}{l}\text { Noncent. } \\
\text { Paramete } \\
r\end{array}$ & $\begin{array}{l}\text { Observed } \\
\text { Powerc }\end{array}$ \\
\hline \multirow{2}{*}{$\begin{array}{l}\text { Corrected } \\
\text { Model }\end{array}$} & Pretest & $334.803 a$ & 2 & 167.401 & 1.528 & .230 & 3.057 & .304 \\
\hline & Posttest & $1526.743 b$ & 2 & 763.372 & 9.045 & .001 & 18.090 & .963 \\
\hline \multirow{2}{*}{ Intercept } & Pretest & 40644.379 & 1 & 40644.379 & 371.072 & .000 & 371.072 & 1.000 \\
\hline & Posttest & 59631.664 & 1 & 59631.664 & 706.574 & .000 & 706.574 & 1.000 \\
\hline \multirow{2}{*}{ Kelas } & Pretest & 334.803 & 2 & 167.401 & 1.528 & .230 & 3.057 & .304 \\
\hline & Posttest & 1526.743 & 2 & 763.372 & 9.045 & .001 & 18.090 & .963 \\
\hline \multirow{2}{*}{ Error } & Pretest & 4052.697 & 37 & 109.532 & & & & \\
\hline & Posttest & 3122.632 & 37 & 84.395 & & & & \\
\hline \multirow{2}{*}{ Total } & Pretest & 179950.000 & 40 & & & & & \\
\hline & Posttest & 251925.000 & 40 & & & & & \\
\hline \multirow{2}{*}{$\begin{array}{l}\text { Corrected } \\
\text { Total }\end{array}$} & Pretest & 4387.500 & 39 & & & & & \\
\hline & Posttest & 4649.375 & 39 & & & & & \\
\hline
\end{tabular}

traditional and non-traditional learning is Machisella's research [10]. The results of the research of these two figures show that every educator must pay attention to the advantages and disadvantages of using traditional and non-traditional learning models. This is because every decision from 
Table 5. Control and Experiment Class Learning Motivation Data

\begin{tabular}{|c|l|c|c|}
\hline No & Item & $\begin{array}{l}\text { Control } \\
\text { Class }\end{array}$ & $\begin{array}{l}\text { Experiment } \\
\text { Class }\end{array}$ \\
\hline 1. & The attractiveness of the learning model used & $60 \%$ & $95 \%$ \\
\hline 2. & The attractiveness of the learning media used & $65 \%$ & $100 \%$ \\
\hline 3. & $\begin{array}{l}\text { The high level of student learning motivation when learning } \\
\text { is carried out }\end{array}$ & $70 \%$ & $100 \%$ \\
\hline 4. & $\begin{array}{l}\text { The level of students' understanding of the teaching } \\
\text { materials explained by the teacher }\end{array}$ & $65 \%$ & $98 \%$ \\
\hline 5. & $\begin{array}{l}\text { The level of student enjoyment when the teacher uses } \\
\text { learning models and media }\end{array}$ & $55 \%$ & $100 \%$ \\
\hline
\end{tabular}

As stated in Table 5 above, the results of this study also show that the use of problem-based learning models (non-traditional learning models) has an impact on mathematical reasoning and student learning motivation. The problem-based learning model or better known as the PBL abbreviation has taught students to become learners who are ready for future challenges. This is because the use of the PBL learning model includes all things including skills, dexterity, and foresight in making decisions as a solution to problem-solving [11]. In addition, the impact of using the PBL model in learning is to help students to be more actively involved in learning so that the value of student knowledge also has a better effect. [12]

It is different from other studies that look at the effectiveness of using the PBL model in terms of student activity in carrying out the learning process. However, this study emphasizes that there is an effective use of the PBL learning model in terms of students' mathematical reasoning. Students in this study who are faced with a mathematical problem will have a much better mathematical reasoning process than students who are taught using traditional learning models. Students will be more trained, skilled, and agile in making the right decisions as a solution to the problems taken. In addition, the results of this study also show that the learning process carried out in the classroom feels more fun and lively because students are directly involved in every learning activity that has been designed by educators. However, in addition to having the advantages of this PBL learning model, it also has a weakness when an educator cannot bring their students to be actively involved in the learning process. Therefore, when an educator decides to choose the PBL model as a learning model in the classroom, the educator must be prepared to work extra preparing everything including preparing problems that are in accordance with the topics to be taught in class.
Along with the results of this study, the results of research conducted by [13] The PBL learning model has the advantage that it can help students in carrying out critical thinking processes; analyze and solve complex problems in the real world; find, evaluate and use learning resources optimally; train students to work together in teams; demonstrate effective communication skills; and use the knowledge and intellectual skills possessed by students to become a better learner.

In addition to giving a treatment by applying the PBL model, our research team also uses video scribe learning media when the learning process takes place in the experimental class. The results of this study indicate that the video scribe learning media used during the study has a significant influence on students. Learners are very enthusiastic and enthusiastic in participating in the learning process so that it has an impact on the emergence of increased student learning motivation. The existence of increased learning motivation makes it easier for students to carry out the mathematical reasoning process. Another study on the use of video scribe as a learning medium was conducted by [14]. Based on the results of this study shows that the validity test by experts and teachers, learning media based on sparkol videoscribe on the topic of the fifth-grade elementary school ecosystem is declared valid and suitable for use in learning.

The development of learning media sparkol videoscribe as a Fiqh teaching material is worthy of use to increase the motivation in student learning [15]. The research is the same as the results of this study, namely the presence of video scribe media used by teachers can make students motivated to learn. However, the difference lies in the type of research. If the research conducted by Fatimah, et al is a Research and Development study, while this study is a quasi-experimental study. 


\section{CONCLUSION}

The results of the data analysis of this study indicate that the problem-solving learning model and the use of video scribe learning media are considered effective for learning mathematics in the sixth grade of elementary school. The effectiveness of the problem-solving learning model and the use of video scribe learning media in terms of students' mathematical reasoning and students' learning motivation.

\section{REFERENCES}

[1] Trianto, Mendesain Model Pembelajaran Inovatif-Progresif, Jakarta: Kencana Prenada Media Grup, 2011.

[2] Rohman, Strategi dan Desain Pengembangan Sistem Pembelajaran, Jakarta: Prestasi Pustaka Karya, 2013.

[3] M. Uliyandari, E. Candrawati, Problem-Based Learning ToImprove Concept Understanding and Critical Thinking Ability ofScience Education Undergraduate Students, IJORER : International Journal of Recent Educational Research. 2(1) (2021) 65-72. DOI: https://doi.org/10.46245/ijorer.v2i1.56

[4] A. Masek, S. Yamin, The effect of problem based learning on critical thinking ability: A theoretical and empirical review, International Review of Social Sciences and Humanities. 2(1) (2011) 215-221. DOI: https://www.academia.edu/24137089/The_Effec t of Problem Based Learning on the Critical Thinking_of_Students in the Intellectual_and Ethical_Development_Unit?auto=citations\&fr om=cover_page

[5] W. Chen, Teaching geometry through problembased learning and creative design, in Proceedings of the 2013 International Conference on Education and Educational Technologies, Department of Applied Mathematics Tunghai University, Taiwan, 2013, pp 235-238. DOI: http://www.europment.org/library/2013/rhodes/ bypaper/EET/EET-36.pdf

[6] I. Imandala, R. Li, A. Supriyadi, Analysis of problem-based learning models by typology of knowledge Pollock and Cruz, International Journal of Education and Learning, 1(1) (2019) 1-11.DOI: https://doi.org/10.31763/ijele.v1i1.12

[7] C. Kustandi, Media Pembelajaran Manual dan Digital, Bogor: Ghalia Indonesia, 2013.

[8] I. Baharudin, Efektivitas Penggunaan Media Video Tutorial Sebagai Pendukung Pembelajaran Matematika terhadap Minat dan Hasil Belajar Peserta Didik SMA Negeri 1 Bajo Kabpaten Luwu Sulawesi Selatan, Jurnal Nalar Pendidikan, 2(2) (2014) 247-255. DOI: https://doi.org/10.26858/jnp.v2i2.1974

[9] I. Baharudin, Efektivitas Penggunaan Media Video Tutorial Sebagai Pendukung Pembelajaran Matematika terhadap Minat dan Hasil Belajar Peserta Didik SMA Negeri 1 Bajo Kabpaten Luwu Sulawesi Selatan, Jurnal Nalar Pendidikan, 2(2) (2014) 247-255. DOI: https://doi.org/10.26858/jnp.v2i2.1974

[10] G. A. Tularam, P. Machisella, Traditional vs Non-traditional Teaching and Learning Strategies - the case of learning, INTERNATIONAL JOURNAL FOR MATHEMATICS TEACHING AND LEARNING, 19(1) (2018) 129-158. DOI: https://cimt.org.uk/ijmtl/index.php/IJMTL/articl e/view/21

[11] S. Dole, L. Bloom, K. K. Doss, Engaged Learning: Impact of PBL and PjBL with Elementary and Middle Grade Students, Interdisciplinary Journal of Problem Based Learning, $11(2)$ (2017) 9. DOI: https://doi.org/10.7771/1541-5015.1685

[12] N. W. Suarniati, I. W. Ardhana, N. Hidayah, The Difference between the Effects of Problembased Learning Strategy and Conventional Strategy on Vocational School Students' Critical Thinking Skills in Civic Education, International Journal of Learning, Teaching and Educational Research, 18(8) (2019) 155-167. DOI: https://doi.org/10.26803/ijlter.18.8.10

[13] J. D. Hansen, Using Problem Based Learning In Accounting, Journal of Education for, 81(4) (2006) 2211-2224. DOI: https://doi.org/10.3200/JOEB.81.4.221-224 
[14] L. E. R. Widiari, I. G. Margunayasa, Ecosystem Learning with Sparkol Videoscribe-Based Learning Media, International Journal of Elementary Education, 5(2) (2021) 231-239. DOI: http://dx.doi.org/10.23887/ijee.v5i2.34731

[15] S. Fatimah, M. Sa'diyah, Development of Sparkol Vidoescribe Learning Media to Increase The Students Learning Motivation in Fiqh Subject, JURNAL PENDIDIKAN DAN PEMBELAJARAN, 27(1) (2020) 11-21. DOI: https://core.ac.uk/download/pdf/354311781.pdf 